\title{
CONVERGENCE, SAFETY AND STABILITY OF THE CONTEMPORARY BANKING SYSTEM - SELECTED ISSUES
}

\begin{abstract}
The study is descriptive-systematizing. Selected issues related to the convergence, security and stability of the modern banking system and financial innovations were made. The phenomenon of convergence and institutional-structural features of the models of the financial system were discussed. It also presents the impact of convergence in the financial system on its stability in the theoretical perspective, with particular emphasis on the factors of financial instability in the shot of H.P. Minski. It seems unlikely to analyze changes in financial systems in a holistic way in terms of their similarity. It is more appropriate to analyze modifications, including similarities and differences in financial systems of different countries through the individual elements of these systems. This particularly applies to financial innovations in the product, process and organizational dimension. It was noticed that the elements of the financial system seem to evolve in such a direction that financial innovations show significant similarities in countries with diverse financial systems.
\end{abstract}

Keywords: financial system convergence, stability of banking system, safety of banking system, models of banking system, deregulation.

\section{INTRODUCTION}

The global financial crisis that began in the United States in 2007 is one of the biggest crises in the history of the global economy. Its course can be traced to the model of investment imbalance and financial instability of H. Minsky. It seems that today in the conditions of existing interdependencies between countries and the convergence of financial systems, the international transmission of financial crises is a consequence of progressive convergence.

The aim of the study is to descriptively-systematise the concept of convergence and security of the banking system, and thus to make some kind of introduction to the issue of convergence and its impact on the stability of the modern banking system. The considerations undertaken are a contribution to the further analysis of the problem, including describing and examining the dependencies and their directions between convergence and financial stability. Due to the breadth of the notion, the financial system in the elaboration is limited to the banking system, which in the continental model is its main element, and universal

\footnotetext{
${ }^{1}$ Kinga Stępień, PhD, Jarosław Dąbrowski Military Technical Academy in Warsaw, Department of Logistics, Institute of Security and Defense Systems, gen. Sylwestra Kaliskiego 2b Street, 00-908 Warszawa 46; e-mail: kinga.stepien@wat.edu.pl. ORCID: 0000-0001-6564-3574.
} 
banks accumulate a significant part of the assets of the entire financial system ${ }^{2}$.The study is the author's starting point for a comprehensive analysis of the impact of financial convergence on the stability of the banking system. The research method used in the preparation of this study was the analysis of domestic and foreign literature.

\section{CONVERGENCE OF FINANCIAL SYSTEMS AND INSTITUTIONAL- -STRUCTURAL FEATURES OF MODELS OF THE FINANCIAL SYSTEM}

The national financial systems in recent decades have been influenced by such factors as globalization, deregulation and liberalization, and the development of information and communication technologies. Financial deregulation and innovations introduced in the last two decades of the 20th century stimulated the development of financial markets.

The elimination of barriers between types of financial intermediation and financial services leads to the similarity of financial products and markets. In this sense, one can talk about the convergence of financial systems, which are strongly differentiated and protectionist, evolving towards the single market. A sign of convergence is the increasing importance of the capital market in the accumulation and allocation of capital in the economies of countries in which the continental model of the financial system has developed and the increase of universalism of financial intermediaries leading to the unification of their product offerings and organizational structures.

In the considerations on the convergence of financial systems one can distinguish several threads, which in the most general terms refer to the causes of this phenomenon, the strategy and organizational forms of financial intermediaries and potential threats and risks resulting from the similarity of financial systems (van der Berghe, Verwiere, Carchon, 1999). In the last case, the phenomenon of "financialization" and the financial crisis of 2008 are widely considered (Księżyk [red.], 2013). One of the currents of the debate on the convergence of financial systems is to consider the consequences of globalization and financial deregulation for the internationalization and harmonization of the financial sector regulation system, and thus the model of functioning of financial intermediaries. Ł. Jabłoński points out that the convergence of the regulatory sphere can be treated as a process of countries becoming similar in terms of functioning socio-economic institutions, including formal institutions, which are undoubtedly financial intermediaries and central institutions of the financial system (Jabłoński, 2012). From the previous considerations on the convergence of financial systems, it follows that the discussion focuses on attempts to answer the questions of what are the convergence factors, how it is approached, and how to measure the degree of modeling of the financial system models (Berger, Boot, Thakor, 1997; Mester, 2003; Bos, Kolari, van Lamoen, 2013).

One of the spheres of the market economy in which convergence takes place is the domestic financial system. In general terms, it is a set of commercial institutions and mechanisms allowing the accumulation and allocation of financial capital in the economy. Thus, it is an infrastructure enabling the meeting of supply and demand for capital (the entity side) as well as standards and financial instruments that are used for this purpose (subject). The functions of the financial system are classified in the literature using various criteria. Apart

\footnotetext{
${ }^{2}$ Banking systems in individual countries show big differences. This is a consequence of the regulation that these systems are subject to.
} 
from the deliberations on the differences between the financial system and financial markets, it can be assumed with some simplification that the functions of financial markets are identical to those of the financial system because their implementation by the financial system supports economic development (Balcerowicz, 2001).

The literature on the subject shows that there are basically three perspectives for describing and analyzing the financial system: institutional approach, financial intermediation and functional. The institutional analysis is dominated by a descriptive approach focusing on describing the institutions of the financial system and their activities. A frequently accused allegation is that it is incomplete, but nevertheless sufficient to characterize the structure of the national financial systems and to differ between them. In the second case, the involvement of banks and other financial institutions in the process of financial intermediation is highlighted, taking into account various types of transformations and mitigating the conflict of interests between the capital providers and the borrowers. The key role is played by financial intermediaries (financial institutions), and among them the most important function is fulfilled by banks that transform the acquired funds into long-term capital. It seems that the progressive integration of the functions of financial institutions requires a functional approach that overcomes the limitations of both previous ones. In this case, the emphasis is put on the functions that the financial system implements for the economy (Marton, Bodie, 1995; Schmidt, Hacketthal, Tyrell, 1999; Bodie, Merton, 2000; Allen, Chui, Maddaloni, 2004).

The reasons for the convergence of financial systems can be seen in the processes of consolidation of financial institutions, intensification of cross-border financial operations, technical and technological progress as well as the universalization of banks' offer and creation of financial conglomerates. In addition, in the deregulation and liberalization of most economies and financial innovations, in particular in asset securitization. These factors affect the financial systems in a combined way (Kulawik, 2008). As a result, the modern capitalist economy aims at a model that would combine the features of the financial systems of the most developed world economies, i.e. system convergence.

Taking into account the stages of the evolution of the financial system, at the level of significant generalizations, two basic models of raising capital can be indicated. The criterion for distinguishing these models is the dominant type of financing in a given economy: direct based on financial markets and indirect with the dominant role of financial intermediaries $^{3}$. On this basis, a market model is distinguished, based on financial markets with a significant role of the capital market and, consequently, financial institutions and instruments characteristic of this segment of the financial market (Anglo-American model) and a banking model in which universal banks through a bank loan provide capital to economy (German-Japanese model) ${ }^{4}$. The presented classification, despite the fact that it is probably the most used one, did not resist criticism. The main objections formulated in its direction is the limitation of a group of countries on the basis of which the model of the financial system is determined to the United States of America and the United Kingdom in the case of the market model (Anglo-American) and Germany and Japan in the German-Japanese model, and also a false assumption about the existence of two ideal models of the financial system while in practice both forms may occur in parallel (Matysek-Jędrych, 2007). In ad-

\footnotetext{
3 The model is characteristic of the economy of the USA and Great Britain.

${ }^{4}$ A model characteristic of continental European countries and Japan.
} 
dition, international surveys emphasize that although there is evidence of a relationship between the degree of development of the financial system and the level of economic growth, there is no confirmation that any of the models of the financial system separated on the basis of this classification has a better impact on economic growth (Levine, 2002; Demirguc-Kunt, Huzingo, 2000; Solarz, 2005).

A characteristic feature of the continental model is the acquisition of external financing by enterprises primarily in the form of bank loans granted to them by universal banks. This determines the model of the banking system, which in developed countries is highly concentrated and based on universal banks. Other types of financial intermediaries are less developed (eg investment funds, such as venture capital funds). In this model, universal banks play a dominant role in the financial market and are of particular importance for ensuring efficient, proper, effective and safe functioning of the entire financial system and, as a consequence, of the economic system. In an indirect way, when deciding on the availability of financing sources, banks influence the implementation of investment projects. In the continental model there is also a proper form of corporate governance (corporate governance) consisting in the monitoring of ventures and borrowers by banks.

In the market model, enterprises acquire financial capital primarily through issues of transferable financial instruments (mainly shares). The supply of liquid instruments competing with the classic forms of investing the rate of return on capital is an impulse for the development of this market. As a result, the liquidity and depth of the capital market increases and contributes to easier obtaining of financial capital from this market and to the development of investment funds. They offer investors the opportunity to reduce the investment risk while ensuring a return rate higher than bank deposits. The liquidity characteristic of the stock market creates impulses for obtaining and analyzing information, which increases the probability of achieving profits from completed transactions. The increase in the role of investment funds limits the importance of universal banks, which mainly perform payment and settlement functions (Development of the financial system..., 2014).

The structural features of this financial system model include the financial market as the dominant form of the institution and a clear specialty of financial institutions, including banks that display the profile of a deposit and credit bank or an investment bank. The degree of concentration of the banking system in the Anglo-American model is low, while the segments of the financial market are characterized by high degree of liquidity. In addition, the capital market strengthens corporate governance and facilitates mergers and acquisitions of enterprises.

There is no evidence in the literature for the existence of an advantage of any of the financial system models discussed. It turns out that the impact on economic growth has a degree of development of the financial system, not its structure (Demirguc-Kunt, Huzingo, 2000; Demirguc-Kunt, Feyen, Levine, 2011). In practice, you can talk about a certain "complementation" of both models in different proportions and the following relationships:

- the high-growth and liquidity stock market can offset the negative effects of the banks' advantage over enterprises,

- banks and markets provide financing for diversified business entities.

A cross-sectional study on the convergence of financial systems in Europe in the period 1980-1998 shows that it was impossible to talk about financial systems becoming similar. The German financial system was close to the continental model with the dominant role of universal banks, while the structure of the financial system in the United Kingdom demon- 
strated the characteristics of the market model. However, the changes in the structure of the financial system in France have been noticed, which is difficult to clearly identify as a continental or market one (Schmidt, Hackethal, Tyrell, 2001). This statement is confirmed by more recent studies, which are a comprehensive international comparative analysis of the structure of the financial system. It shows that four groups of countries can be distinguished due to the criterion of financial market dominance or banks in the financial system (Bijlsma, Zwart, 2013). Firstly, countries with market financial systems (the Netherlands, the United Kingdom, Belgium, Finland, France and Sweden), secondly countries with a model of a financial system dominated by banks (Austria, Denmark, Germany, Greece, Italy, Portugal, Spain), then the financial system of the countries of Central and Eastern Europe (Bulgaria, the Czech Republic, Estonia, Hungary, Latvia, Lithuania, Poland, Romania, Slovakia and Slovenia) and others (Ireland, Malta, Cyprus, Luxembourg), which are characterized by a very large banking sector and a high ratio of loans to GDP.

A general analysis of the structure of the financial system in Poland leads to the conclusion that it is close to the banking model. In the assets of the financial system, the largest share is held by banks (around 85\% of GDP), which are the main providers of capital for the enterprise sector. In recent years, however, it can be noted that the importance of banks in the financial system is reduced in favor of other financial intermediaries (insurance companies, pension and investment funds) active in the capital market. This is probably the result of the growing level of development, higher liquidity and depth of the Polish capital market.

\section{STABILITY AND SECURITY OF THE BANKING SYSTEM}

The stability of the banking, financial and economic system gained in importance at the beginning of the 21 st century. This was mainly due to the negative effects of the financial crisis 2007-2008, which severely affected many countries at different levels of development. Comparative arguments from international comparative studies suggest that the efficiency of institutions creating and operating within the banking and financial system significantly determine the functioning of the economic system per se on the one hand, and on the other is an important factor stabilizing the course of real economic processes, ie growth and economic development (Barlevy, Tsiddon, 2006; Bordo, Meissner, 2011; Beer, 2012). Negative experiences of this crisis have shown that disruptions in the area of stability may cause disturbances on the financial markets and in the real economy. Therefore, the efficiency of banking and financial systems is or should be the goal of not only the institutions of the state acting as a macroregulator of real processes, but also institutions that are part of the financial sphere of the economy.

The experience of banking indicates the existence of dependence between the reliability and good condition of banks and economic efficiency. The efficiency of the banking system determines the functioning of modern economies. This is confirmed by the relationship between the degree of development of financial markets and the economy (Levine, 1996; Wojtyna, 1997; Summers, 2000; Kose, Prasad, Rogoff, Wei, 2006). A. Wojtyna explains that theoretical and empirical studies seem to confirm the hypothesis about the significant influence of modernity and the stability of the financial system on the rate of economic growth. With the increase in real national income per capita, the share of financial institutions in creating national income (financial deepening) increases. In practice, this means 
that an increasing portion of assets takes the financial form. In the conditions of rapid economic development, the increase in the average value of assets of financial institutions to national income is also faster. Therefore, it is legitimate that in each state, due to the functions performed, the efficiency of the banking sector is an essential factor in the development of the entire economy. Disruptions in the functioning of the banking system may jeopardize the stability of the entire economy, including by disrupting the process of collecting funds and allocating them for investment. Central banking system institutions play an unrivaled role in ensuring the stability of the banking system. Against the background of the 2007-2008 crisis, it can be said that the shape, development and functions of the Financial Safety Net (SBF) should adapt to the changing conditions of the internal and external environment.

In the literature on the subject, there is a discussion on the concept of financial stability. The conclusions from it lead to the conclusion that the issue of defining financial stability can be approached in two ways: specifying what is financial stability or by defining the opposing concept - financial instability (Zygierewicz, 2013). The existing definitions emphasize the relationship between the financial system and the real sphere of the economy: on the one hand, the condition of the economy depends on the efficiency of the financial system, and on the other hand the state of the economy may be the source of external shocks that disturb the system. At the same time, the financial system alone is able to prevent crises (Szczepańska, Sotomska-Krzysztofik, Pawliszyn, Pawlikowski, 2004). The stability of the financial system is also defined as a state in which the financial system performs all its functions in a continuous and effective manner, even in the event of unexpected and unfavorable disturbances on a large scale (Solarz, 2001). It is noted that in conditions of banking system stability there may be incidental problems in some institutions, changes in asset prices or bank failure. However, as long as they do not threaten the entire banking system, the stability of the banking system is still being discussed.

The financial crisis of 2007-2008 has significantly contributed to the attempt to redefine the security and financial stability and the role of the SBF institution in its provision. The analysis of the literature, however, leads to reflection that attention is focused on systemic risk and providing prudential solutions adequate to its scale. Attempts are made to identify and classify sources of financial instability (Global Financial Stability Report..., 2008; Bullard, Neely, Wheelock, 2009).

\section{CONSEQUENCES OF FINANCIAL SYSTEM CONVERGENCE FOR SECURITY AND STABILITY IN THE THEORETICAL PERSPECTIVE}

The financial convergence that has taken place in the banking system in the last two decades of the 20th century and at the beginning of the 21 st century, beyond the undisputed positive influence, also caused threats to its security and stability. Most of these threats may be associated with the already mentioned processes of globalization, financial liberalization and progress. technology. The IMF surveys show that these threats can be divided into: macroeconomic sources of instability and sources specific to the banking sector (sectorspecific sources). One of the economists who thoroughly examined and comprehensively explained the crisis phenomena in the economy, including the reasons for the instability of the financial system was H.P. Minsky (Minsky, 1986). In his research he paid attention that the economically dramatic events of the Great Depression and the Second World War following them, resulted in the development of solid stabilization mechanisms in the American 
economy. However, the stable structure of the financial system being a legacy after the Second World War and the financial conservatism developed as a consequence of the "Great Depression" disorders (which together contributed to the stability of the system), over the years lost their importance under the influence of new economic trends. As a result, the deregulation of the 1980s has evolved a new structure of the financial system, on the one hand more flexible, with significant benefits for market participants with an open approach to innovative market practices, on the other hand more complex, less stable and more prone to crisis. As Minsky rightly pointed out, in different periods the economy operates differently and its mechanisms are subject to the impact of diverse conditions. For example, the American economy of the 1970s and 1980s was more volatile than it was in the 1950s, in the early 1960s and even in the 1960s, and this should be attributed to, among other things, changes in the structure of financial liabilities and in changing financial standards. The financial standards are reflected in the conditions for settling liabilities. These conditions reflect the current trends in the financial markets and expectations as to their future changes.

According to Minsky, one of the important reasons for the sensitivity of the modern financial system can be considered changes in the structure of financing enterprises and households. Today, to a much greater extent than even a few decades ago, both enterprises and households finance their current projects (consumption) and investment projects from external funds obtained on the financial market. The greater than ever exposure of companies and individuals to the financial market, including in particular its debt segment, makes the financial condition of these entities to a greater extent dependent on the current conditions on the financial markets and vice versa - the stability of the financial market to a greater extent than ever before depends on the condition of enterprises and households participating in operations on this market. As another reason for the greater vulnerability of the modern financial system to crisis phenomena one should indicate changes in the structure of liabilities of business entities; in recent decades, the share of short-term liabilities has been gradually increasing at the expense of long-term liabilities. It results from the tendency to finance long-term investment undertakings of companies with short-term indebtedness, which is then rolled up. The main reason for the more risky deviation from longterm financing to short-term financing includes higher costs of servicing long-term debt, whether in the form of loans or issuance of debt securities. Under normal conditions, shortterm interest rates are lower than long-term rates, due to the risk of financing, higher in the long run. The consequence of changes in the structure of liabilities is related to another reason for the sensitivity of the modern financial system, namely the repayment of liabilities from the ability to incur new ones. Nowadays, payable liabilities, both in their interest part and in the capital part, are regulated by funds generated internally by the company (eg revenues from the sale of goods or services) or by households (remuneration), while the form of regulating matured liabilities due to their refinancing, ie the repayment of liabilities from funds obtained from a new loan (rollover), is becoming more and more popular. The reason for susceptibility to crisis phenomena of the modern financial system can also be seen in the dynamic development of the segment of "exotic" financing instruments. Because the "inventors" who are rewarded with the interest of issuers and investors and finally additional revenues for the creation and successful launch of a new generation financial instrument, entire staffs of professionals and financial engineers are working on more and more exotic and dynamic solutions for the financial market. 
Deregulation also introduced changes in the concept of regulating the financial market. Modern "legislative thought" aims at influencing economic processes to a minimal extent, only in what it is necessary to stimulate economic growth. Legislation also affects the mechanisms of the financial market (through legal acts and central bank policy) and attitudes of participants in this market, but the legislative initiative in the field of financial market is undertaken mostly only in those areas in which the market directly affects the real economy. As Minsky pointed out, one of the most important reasons for the greater crisis threat of the modern financial system is the increase in risk appetite among financial institutions. Banks, like most business entities, are institutions geared to profit in their operations. Banks also have their owners - shareholders who in return for providing capital institutions (through the purchase of shares) have specific expectations as to the rate of return on this investment. Because the relationship between risk and return on investment has a positive slope, only by accepting a higher level of risk, banks are able to generate high returns on capital for their owners. It can also be said that the growing tendency of banks to risk in recent decades was "supported" in the past by government intervention measures in critical moments for the banking sector; Bankrupt banks on the verge of bankruptcy received government assistance.

\section{SUMMARY}

The article attempts a descriptive-systematizing approach to the phenomenon of convergence, security and stability in the banking system, and thus introducing the issue of convergence and its relationships with the mentioned categories. On the basis of the considerations, some observations may be made, which, however, are not general conclusions. These require further research into the relationships of financial convergence with the security and stability of the banking system.

First the issue of financial stability and security can be considered from the perspective of institutional, functional and regulatory changes understood as convergence. Models of financial systems are constantly changing under the influence of conscious or unintentional actions. In addition to shocks and technological changes, the evolution of national coordination mechanisms (macroregulation, economic policy), these models are subject to modifications, especially under the influence of globalization resulting from the expansion of global capitalism.Financial stability is a public good in a market economy. Secondly the importance of financial stability results from the role and functions of financial institutions in the economy, regardless of the model of the financial system. There is agreement that the stability of the banking system is a sine qua non condition for maintaining the stability of the entire financial system, which together with its security determines the smooth and proper functioning of financial markets. Thirdly it was noted that the definitions of financial stability underline the relationship between the condition (safety, situation) of the financial systemand the real sphere of the economy. This means that the economic situation may cause disruptions in the functioning of the system. However, it should be emphasized that the financial system may operate even under conditions of individual disturbances (incidental problems in some institutions, changes in asset prices), as long as they do not destabilize the whole financial system. Fourthly, the convergence in the financial system, except for the positive phenomena, also brought about other threats that can be divided into: macroeconomic sources of instability and sources specific to the banking sector. According to H.P. Minsky deregulation in the 1980s has developed a new, more flexible structure of the 
financial system, which provides benefits for market participants with an open approach to innovative market practices. However, due to its complex structure, it is less stable and more vulnerable to the occurrence of crises. Important reasons for the possible instability of the modern financial system include changes in the structure of financing enterprises and households, making repayment of liabilities conditional on the ability to incur new ones and an increase in risk appetite among financial institutions.

\section{REFERENCES}

Allen, F., Chui, F., Maddaloni, A. (2004). Financial Systems in Europe, the USA and Asia. "Oxford review of Economic Policy” Vol. 20 (4).

Balcerowicz, L. (2001). Convergence of systems. “Wprost” Nr 15 (959).

Barlevy, G., Tsiddon, D. (2006). Earnings inequality and business cycle. "European Economic Review" Vol. 50.

Berger, A.N., Mester, L.J. (2003). Explaining the dramatic changes in performance of US banks: technological change, deregulation and dynamic changes in competition. "Journal of Finanancial Intermadiation” No. 12 (1).

Bijlsma, M.J., Zwart, G.T.J. (2013). The changing landscape of financial markets In Europe, the United States and Japan. “CPB Discussion paper” No. 238, Hague, 26 March.

Bodie, Z., Merton, R.C. (2000). Finance. Upper sadole River, Prentice Hall.

Boot, A.W., Thakor, A.V. (1997). Banking scope and financial innovation. "Review of Financial Studies” No. 10 (4).

Bordo, M.D., Meissner, C.M. (2011). Do financial crises always raise inequality? Some Evidence from History, JIMF 4th Annual Conference at UC Santa Cruz, 23-24, September 2011, Santa Cruz, USA [Access: 10.10.2012]. Access on the internet: www. sciie.ucsc.edu

Bullard, J., Neely, C.J., Wheelock, D.C. (2009), Systemic Risk and the Financial Crisis: A Primer, Federal Reserve Bank of St. Louis Review, September/October, 91(5), Part 1.

de Beer, P. (2012). The impact of the crises on earnings and income distribution in the EU, European Trade Union Institute, 2012, ETUI Working Paper.

Demirguc-Kunt, A., Feyen, E., Levine, R. (2011), The Evolving Importance of Banks and Securities Markets, "Policy Research Working Paper", The World Bank, No. 5805.

Demirguc-Kunt, A., Huzingo, H. (2000). Financial Structure and Bank Profability. "Policy Research Working Paper”, The World Bank Development Research Group Finance.

Development of the financial system in Poland in 2013, NBP, Warsaw 2014.

Global Financial Stability Report. Containing Systemie Risks and Restoring Financial Soundness, IMF, April 2008.

Jabłoński, L. (2012). Human capital versus economic convergence. Warsaw: C.H.Beck.

Kose, M.A., Prasad, E., Rogoff, K., Wei, S.J. (2006). Financial globalization: A reappraisal. "IMF Working Paper" No. 189.

Księżyk, M., ed. (2013). Liberal capitalism in a crisis. Selected problems, Krakow: Academy of A. Frycz- Modrzewski.

Kulawik, J. (2008). European financial and monetary integration and agriculture, Warsaw: Institute of Agricultural Economicsand Food Economy, National Research Institute.

Levine, R. (1996). Financial development and economic groth: Views and agenda. "Journal of Economic Literature" Vol. 35, No. 2. 
(2002). Bank-Based or Market-Based Financial System: Which is Better?. "Journal of Financial Intermediation" Vol. 11, Issue 4.

Matysek-Jędrych, A. (2007). Structure and models of the financial system. "Bank i Kredyt", Vol. 38, No. 11-12.

Merton, R.C., Bodie, Z. (1995). A Conceptual Framework for Analyzing the Financual Enviroment [in:] Crane, D.B., ed., The Global Financial System: A Functional Perspective. Boston MA Harvard Business School Press.

Minsky, H.P. (1986). Stabilizing an Unstable Economy, Yale University Press.

Schmidt, R.H., Hackethal, A., Tyrell, M. (2001),, The Convergence of Financial Systems in Europe. “Working Papers Series Finance and Accounting” No. 75, Johan Wolfgang Goethe Universitat, Frankfurt am Main, Fachbereich Wirtschaftswissenschaften.

_ (1999). Disintermediation and the Role of Banks in Europe: An International Comparison. "Journal of Financial Intermediation".

Solarz, J.K. (2001). International financial system. Institutional and comparative analysis. Warsaw: Library of the Manager and Banker.

(2005). Institutional order of financial policy [in:] Kulawik, J., Mazurkiewicz, E., ed., Poland's financial policy in the face of current and future challenges. Warsaw: University of Economics in Warsaw.

Summers, L.H. (2000). International Financial Crises: Causes, Prevention and Cures. "The American Economic Review", Vol. 90, No. 2.

Szczepańska, O., Sotomska-Krzysztofik, P., Pawliszyn, M., Pawlikowski, A. (2004). Institutional determinants of financial stability on the example of selected countries. "Materials and Studies” No. 173, NBP, Warsaw, April.

van der Berghe, L.A.A., Verwiere, K., S.W.M. Carchon, S.W.M. (1999). Convergence in the Financial Services Industry, OECD Report.

Wojtyna, A. (1997). Fundamentals of sustainable economic growth and policy, RSSG at the Council of Ministers, Report No. 13, Warsaw.

Zygierewicz, M. (2013). Financial stability. “Annales Universitatis Mariae Curie-Skłodowska Lublin - Polonia”, Sectio H, Vol. XL VII, 3.

DOI: $10.7862 / \mathrm{rz} .2019 . \mathrm{mmr} .14$

The text was submitted to the editorial office: October 2018.

The text was accepted for publication: June 2019. 